\title{
Islam in Global History
}

\author{
Nazeer Ahmed \\ Concord, California: American Institute of Islamic \\ History and Culture, 2000. 861 pages.
}

Islam in Global History, written in two volumes covering the period from the death of the Holy Prophet to the First World War, has the distinction of being a book on history and the philosophy of history. This is because, as the reader discovers, it is not merely a chronicle of events of the Muslim world from the advent of Islam to the end of the World War I; it is a book which provides insights into the causes of the victories and defeats of dynasties as well as successes and failures of movements in Islamic history, and lays down the laws for the rise and fall of civilizations.

Certainly, he is not the first in the field of the philosophy of history. The two stalwarts who made original and remarkable contributions in this field during the last two millennia are Ibn Khaldun and Arnold Toynbee. The books in which they propounded their theories of the interpretation of history are not books on history as such. Historical data were, no doubt, used and analyzed to substantiate their theses. Ibn Khaldun proved his concept of asabiyah (social group cohesion) in the context of the history of the Arabs and the Berbers, which he was to write subsequently. Toynbee used the data from world history to prove his idea of "Challenge and Response" to be the determining factor in the strength and decay of civilizations and societies. It is to the author's credit that such a comprehensive and coherent work on Islamic history has been produced. At each critical stage he diagnosed the causes of the major events that went into making watersheds and turning points in Muslim history worldwide.

Dr. Ahmed is an eclectic writer who has partially benefited from the concepts of the interpretation of history expounded by lbn Khaldun and Toynbee. For example, he agrees with lbn Khaldun when he says:

The origins of the Ottoman Empire are to be found in a combination of Turkish asabiyah, a term used by Ibn Khaldun to denote tribal cohesion, the force that holds together tribes through bonds of blood, a characteristic found in abundance among peoples of the desert and the nomads off the steppes.

He concurs with Toynbee when he writes:

Great civilizations measure up to their challenges and grow more resilient with each crisis, turning adversity into opportunity. Critical moments in his- 
tory test the mettle of humans. Great men and women bend history to their will, whereas weaker ones are swallowed up in the convulsions of time.

He finds, however, Ibn Khaldun's concept of 'asabiyah deficient in the context of the interpretation of the history of Islamic nations and civilization. He rightly feels that while the concept of asabiyah does play the determining role in shaping the destiny of people outside the fold of Islam (and perhaps the people who pay Islam mere lip service, since Islam discourages all types of 'asabiyah). Thus he writes: “... However, Ibn Khaldun's ideas present enormous difficulties in [an] Islamic perspective. Islam is against 'asabiyah based on race, color or national origin."

As an alternative, Dr. Ahmed has formulated his own theory for the interpretation of history: the principle of "self-renewal," which, according to him, makes renewal of Islam possible through regeneration, vanguarded by the recurrent appearance of reformers. "Century after century," he writes,

from the al-Muhaddith of the Maghrib to Uthman Dan Fodio of Nigeria and the Mahdi of Sudan [also Mujaddid Alf Thani of Sirhind, Shah Waliullah of Delhi and Dr. Muhammed Iqbal of Lahore, who have been named as reformers in the book elsewhere], one sees this recurrent attempt at renewal of Islamic life and a regeneration of Islamic civilization.

He considers the idea of tawhid, rather than the tribal 'asabiyah, as the force binding Muslims of different tribes and ethnicities together. "Ideas are the glue, the cement, the force and the power that hold people together ... at the core of Islam is the idea of tawhid." He expounds his own theory of the philosophy of history more explicitly in the following words: "It is our thesis that the causes of the rise and fall of Muslim societies are to be found in the internal dialectic of the community. Islamic history revolves around the axis of faith."

It is a pleasant surprise to find a person like Dr. Ahmed making such an original and remarkable contribution in the field of philosophy of history, a field not directly linked with his academic background and career as a scientist.

You will find innumerable quotable observations, the pearls of wisdom, scattered and shining like jewels throughout the pages of the book. His mastery of the English language, which is not his mother tongue, and the vastness of his vocabulary make him stand out even above several celebrated authors whose mother tongue is English. In clarity of thought and expression, while expounding his viewpoint, he surpasses even writers like Toynbee. At places, his style reminds one of Carlyle, in the flow of ideas 
and beauty of expression. His book on history can be compared to Will Durant's Story of Philosophy. He has made a potentially dry subject like history into enjoyable reading, just as Durant has done. Indeed, the book is as much a book of literature as it is a book on history and the philosophy of history. One cannot escape the charm of words while reading the book. As a philosopher of history, among the Muslims, I would not hesitate to allot to Dr. Nazeer Ahmed a place next only to Ibn Khaldun.

After paying rightly deserved tributes, it will not be out of place to make a couple of suggestions for the improvement of the book: in the first place, the binding of the soft-cover copy of the book is too loose. In the second reading, the leaves start falling apart. This good book deserves to be preserved in public and personal libraries. It may, therefore, be suggested that the publisher should ensure a more secure and sturdier binding in the next issue; secondly, there are a number of spelling errors and a few other typographical mistakes and omissions, which need to be removed in the next edition.

Niaz. Erfan

Retired, Former World Bank Project Preparation Liaison Officer for Educational and Examination Reforms in Pakistan and Joint Educational Advisor to the Government of Pakistan Islamabad, Pakistan 